\title{
STUDY OF THE COPPER, CHROMIUM AND LEAD CONTENT IN MUGIL CEPHALUS AND ELEGINOPS MACLOVINUS OBTAINED IN THE MOUTHS OF THE MAULE AND MATAQUITO RIVERS (MAULE REGION, CHILE)
}

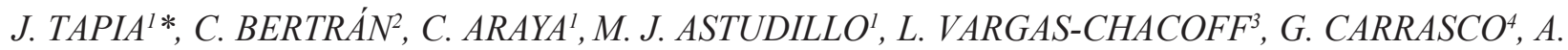 \\ VADERRAMA' AND L. LETELIER'.
}

\author{
${ }^{1}$ Institute of Natural Resources Chemistry, University of Talca, Post 747, Talca, Chile. \\ ${ }^{2}$ Institute of Zoology, Science Faculty, Austral University of Chile. Valdivia, Chile. \\ ${ }^{3}$ Biology Department, Faculty of Marine Sciences, University of Cadiz, Cadiz, Spain. \\ ${ }^{4}$ Faculty of Agrarian Sciences, University of Talca, Talca, Chile.
}

(Received 28 February 2008 - Accepted 13 January 2009)

\begin{abstract}
The $\mathrm{Cu}, \mathrm{Cr}$ and $\mathrm{Pb}$ concentrations were determined in Mugil cephalus and Eleginops maclovinus, fish species inhabiting the mouths of the Maule and Mataquito Rivers (Maule Region, Chile) which are consumed by the coastal population in large quantities. Measurements were taken by flame atomic absorption spectroscopy to analyse representative muscle tissue of the two species. The method was validated using certified reference material (DOLT-1). The concentration ranges of $\mathrm{Cu}, \mathrm{Cr}$ and $\mathrm{Pb}\left(\mathrm{mgkg}^{-1}\right.$, dry weight) in Mugil cephalus from the Maule river were: $\mathrm{Cu} 0.5-36.2 ; \mathrm{Cr} 0.3-6.3 ; \mathrm{Pb} 0.4-11.2$ and from the Mataquito river varied between: $\mathrm{Cu}$ 0.6-23.2; $\mathrm{Cr}$ 0.3-6.0 and $\mathrm{Pb}$ 0.4-11.1. For the species Eleginops maclovinus from the Maule river the concentration ranges were: $\mathrm{Cu}$ 0.8-13.2; $\mathrm{Cr}$ 0.2-5.6; $\mathrm{Pb} 0.2-9.6$ and from the Mataquito river: $\mathrm{Cu} 0.5-18.4 ; \mathrm{Cr} 0.2-3.2$ and $\mathrm{Pb} 0.3-4.0$. The concentration ranges of $\mathrm{Cu}$ and $\mathrm{Cr}$ recorded in the two species of fish are within the levels permitted by FAO and EPA, however the concentrations of $\mathrm{Pb}$ in Mugil cephalus originating from both estuaries exceeds the levels permitted by current legislation. The statistical analysis done with one way ANOVA $(p<0.05)$ indicated that for each metal there are no significant differences between the species and the two sampling sites; however with two way ANOVA between the species and the two sampling sites a significant difference was found for $\mathrm{Cu}$ and $\mathrm{Cr}$, but not for $\mathrm{Pb}$.
\end{abstract}

Keywords: Heavy metals, Fish, Atomic absorption spectrometry, Maule - Mataquito Rivers

\section{INTRODUCTION}

In recent decades special attention has been paid to learning about the presence of toxic materials in river mouths and estuarine zones, where large quantities of contaminants are concentrated originating from industrial and domestic waste, generated especially by big cities ${ }^{1-2}$. Unlike organic contaminants, heavy metals do not suffer biological or chemical degradation in nature; the compounds which contain them may be altered, but the toxic metals remain and their stability means that they may be transferred over considerable distances and bioaccumulated in aquatic organisms of the trophic chain, such as fish, which then constitute a danger to human health when used for food ${ }^{3}$.

Fish are more sensitive than invertebrates to toxic metals, and their metabolism acting principally through the liver, kidneys, pancreas and muscle is seriously damaged in the presence of these metals. The pathological damage produced in fish allows the toxicity of the environment to be defined, making them highly suitable for evaluating the quality of an aquatic system ${ }^{4-9}$.

Today, there are considerable proofs to show that heavy metals signify a threat to human health when ingested in sufficient quantities, and therefore special attention should be paid to the areas used by man for obtaining his food, since they are generally the same areas where he discharges the waste from all his activities ${ }^{10-12}$. For this reason, there is particular interest in studying the degree of contamination in river mouths, which provide the majority of the nutrients consumed by the marine species used by $\operatorname{man}^{3}$.

In Chile, there are a number of geographical zones exposed to the toxic effects of certain chemical compounds, including the Maule Region where important urban, industrial and agroforest development has occurred ${ }^{13-15}$ This fact has caused an alarming increase in the volumes of waste which are dumped directly into the nearest bodies of water in the Region. The cumulative effects of these chemical contaminants cause a serious deterioration in the aquatic environment $t^{16-17}$. The distribution of certain heavy metals in an aquatic ecosystem depends, among other things, on the physical-chemical characteristics of the waters and the capacity for bioaccumulation of the organisms which compose the biota ${ }^{18-19}$.

The principal hydrographic systems of the Maule Region are the Maule and Mataquito river basins. The Maule river basin covers an area of 20.600 $\mathrm{km}^{2}$ and receives the discharges of the cities of Talca (201.797 inhabitants) and
Linares (83.249 inhabitants) via the Claro and Loncomilla rivers respectively. The Mataquito river basin, with its tributaries Teno and Lontué, covers an area of $5.240 \mathrm{~km}^{2}$ and receives principally the discharge of the city of Curicó, population 19.585 inhabitants $^{20}$. Both hydrographic systems receive the impact of domestic and industrial waste, the latter resulting basically from the processing of agricultural produce, the food and soft drinks industries, leather tanning, and the wood industry and its derivatives.

The contamination of aquatic environments by heavy metals and their subsequent impact on organisms is dramatic in estuaries, especially when these are close to towns or industrial zones. In the present study, two wood pulp plants were recorded: Constitución and Licantén, located close to the mouths of the Maule and Mataquito rivers respectively ${ }^{21}$.

The majority of the work published using organisms as bioindicators for contamination have concentrated on invertebrates, principally molluses and crustaceans. However the use of fish as indicators of aquatic contamination is today widely recognised ${ }^{22-26}$.

In the present work, the concentrations of copper, chromium and lead were studied in muscular tissue of fish of the species Mugil cephalus and Eleginops maclovinus, taken from the mouths of the Maule and Mataquito rivers. Both species are typical of estuarine zones and are extensively consumed by the local population. The concentrations of the various metals in the two species will enable the degree of contamination of the two hydrographic systems to be diagnosed, and variations in the concentrations of the metals between the two species to be detected. At the same time, the results obtained may be compared to similar studies carried out by other authors and with the international norms currently in force with respect to the content of metals in fish for human consumption.

\section{EXPERIMENTAL}

\section{Study area}

Considering the hydrographic basins of the Mataquito and Maule rivers, in the north and south of the VII Region respectively, two sampling zones were selected, corresponding to the mouths of the two rivers, located in Iloca for the Mataquito river ( $\left.35^{\circ} 00^{\prime} 57^{\prime \prime} \mathrm{S}-72^{\circ} 10^{\prime} 52^{\prime \prime} \mathrm{W}\right)$ and Constitución for the Maule river ( $\left.35^{\circ} 19^{\prime} 06^{\prime \prime} \mathrm{S}-72^{\circ} 24^{\prime} 32^{\prime \prime} \mathrm{W}\right)$. Fig. 1 shows the geographical locations of the points selected. 


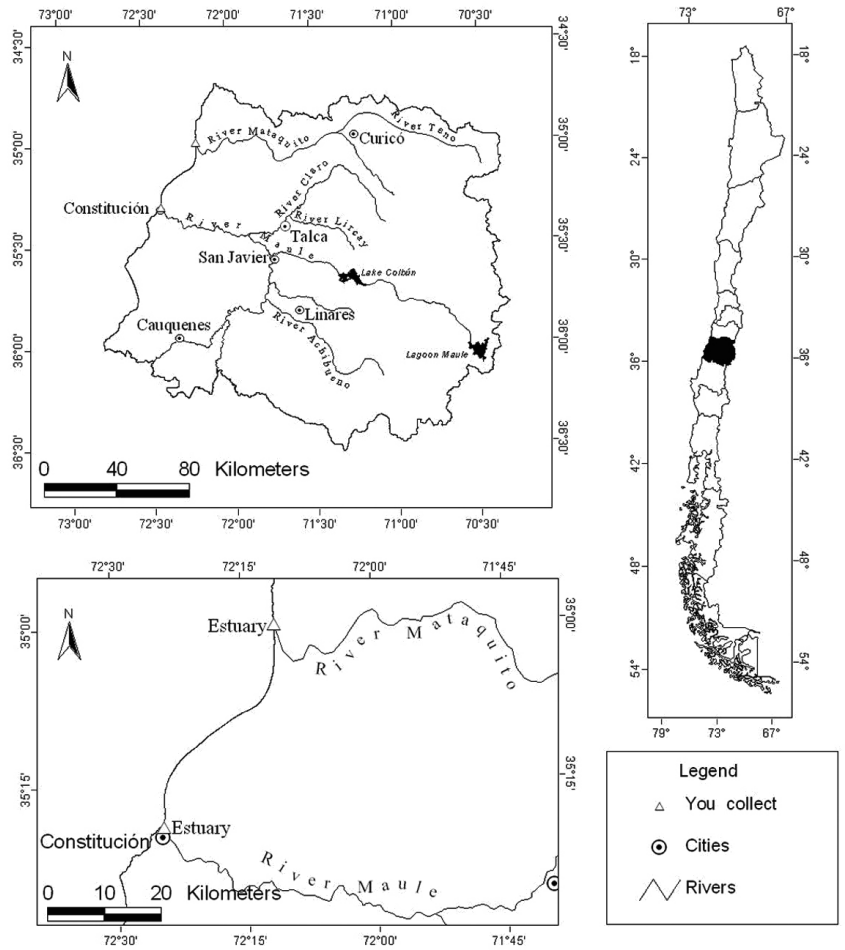

Figure 1. Geographical location of the mouths of the Maule and Mataquito rivers Maule Region, Chile)

\section{Sample taking}

Samples were taken in four collection campaigns at the mouths of the Maule and Mataquito rivers (VII Region, Chile). The first in July (winter) and the second in October (spring) 2005, the third in April (autumn) and the fourth in December (summer) 2006. The samples were collected by purchase at the point where they are brought ashore by local fishermen whose livelihood is to catch and sell Mugil cephalus (lisa) and Eleginops maclovinus (róbalo) in the towns of Constitución and Iloca, located at the mouths of the Maule and Mataquito rivers respectively.

The fish were gutted in the field and plastic material was used to extract part of the muscle, which was immediately placed in a freezer in pre-treated and labelled plastic containers, until it could be treated chemically.

\section{Chemical treatment}

The reagents used were of high purity (Suprapur, Merck, Darmstadt, Germany). The cleaning of the material was fundamental to guarantee optimum results in analysis. The plastic and glass material was washed with non-ionic detergent and abundant deionised water, then treated with a solution of nitric acid $\left(\mathrm{HNO}_{3}\right) 10 \% \mathrm{v} / \mathrm{v}$ for 48 hours, and finally rinsed three times with bidistilled water.

The samples of muscle were lyophilized to a constant weight, using a Labconco lyophilizer, ground and strained through a $0.5 \mathrm{~mm}$ nylon mesh. The samples were homogenised and kept in pre-treated plastic containers for subsequent analysis.

For digestion, $1.0 \mathrm{~g}$ of sample was weighed out and $10 \mathrm{~mL}$ of Suprapur nitric acid was added. The samples were then dried almost completely under an extractor fan, with constant stirring, using a heating plate set to $90^{\circ} \mathrm{C}$. The resulting solution was filtered and washed with bidistilled water, and made up to a final volume of $25 \mathrm{~mL}$ in a pre-treated volumetric flask. The analyses were done in triplicate with a control solution for each.

The measurements were done by flame atomic absorption spectroscopy, using a Unicam spectrophotometer mod. 969 with deuterium background corrector.

Validation of the method

The method of analysis was validated using certified reference material
DOLT-1 (fish muscle), supplied by the National Research Council, Canada, NRC, Division of Chemistry. The validation results are shown at Table 1.

Table 1. Concentrations of $\mathrm{Cu}, \mathrm{Cr}$ and $\mathrm{Pb}$ found in Standard Reference Material DOLT-1 (dogfish muscle), from National Research Council, Canada (all data as means \pm standard errors, in $\mathrm{mg} \mathrm{kg}^{-1}$ dry wt).

\begin{tabular}{|l|c|c|c|}
\hline Element & $\begin{array}{c}\text { Certified } \\
\text { concentration }\end{array}$ & Found $^{\mathrm{a}}$ concentration & Recovery (\%) \\
\hline Copper & $20.8 \pm 1.2$ & $21.2 \pm 2.6$ & 101.9 \\
\hline Chromium & $0.4 \pm 0.07$ & $0.37 \pm 0.12$ & 92.5 \\
\hline Lead & $1.36 \pm 0.29$ & $1.48 \pm 0.4$ & 108.8 \\
\hline
\end{tabular}

${ }^{\text {a }}$ Each value is the average of three measurements.

\section{RESULTS AND DISCUSSION}

Tables 2 and 3 show average concentrations, with maximum and minimum values, of $\mathrm{Cu}, \mathrm{Cr}$ and $\mathrm{Pb}$ in representative samples of muscle from Mugil cephalus and Eleginops maclovinus collected at the mouths of the Maule and Mataquito rivers (Maule Region, Chile). A population of 46 representative samples was considered for each species in the two sampling sites.

Table 2. Average concentrations and comparison for $\mathrm{Cu}, \mathrm{Cr}$ and $\mathrm{Pb}$ recorded in samples of fish muscle from Mugil cephalus and Eleginops maclovinus taken from the Maule River (Maule Region, Chile).

\begin{tabular}{|l|c|c|c|c|}
\hline \multirow{2}{*}{ Metals and Species } & $\mathrm{N}$ & \multicolumn{3}{|c|}{$\begin{array}{c}\text { Heavy metal concentrations } \\
\left(\mathrm{mgkg}^{-1} \mathrm{dry} w \mathrm{w}\right)^{\mathrm{a}}\end{array}$} \\
\hline Copper & & Mean & Lower & Upper \\
\hline Mugil cephalus & 46 & 5.9 & $0.5 \pm 0.2$ & $36.2 \pm 4.7$ \\
\hline $\begin{array}{l}\text { Eleginops } \\
\text { maclovinus }\end{array}$ & 46 & 3.6 & $0.8 \pm 0.2$ & $13.2 \pm 2.6$ \\
\hline Chromium & & & & $6.3 \pm 0.7$ \\
\hline Mugil cephalus & 46 & 2.4 & $0.3 \pm 0.1$ & $5.6 \pm 1.6$ \\
\hline $\begin{array}{l}\text { Eleginops } \\
\text { maclovinus }\end{array}$ & 46 & 1.8 & $0.2 \pm 0.1$ & $11.2 \pm 2.2$ \\
\hline Mugil cephalus & 46 & 4.0 & $0.4 \pm 0.2$ & $9.6 \pm 2.3$ \\
\hline $\begin{array}{l}\text { Eleginops } \\
\text { maclovinus }\end{array}$ & 46 & 1.9 & $0.2 \pm 0.0$ & \\
\hline
\end{tabular}

${ }^{\text {a }}$ Each value is the average of three measurements.

Table 3. Average concentrations and comparison for $\mathrm{Cu}, \mathrm{Cr}$ and $\mathrm{Pb}$ recorded in samples of fish muscle from Mugil cephalus and Eleginops maclovinus taken from the Mataquito River (Maule Region, Chile).

\begin{tabular}{|l|c|c|c|c|}
\hline Metals and Species & \multirow{2}{*}{$\mathrm{N}$} & \multicolumn{3}{|c|}{$\begin{array}{c}\text { Heavy metal concentrations } \\
\left(\mathrm{mgkg}^{-1} \mathrm{dry} \mathrm{wt}^{\mathrm{a}}\right.\end{array}$} \\
\hline & & Mean & Lower & Upper \\
\hline Copper & & & & \\
\hline Mugil cephalus & 46 & 6.2 & $0.6 \pm 0.1$ & $23.2 \pm 4.2$ \\
\hline Eleginops maclovinus & 46 & 3.8 & $0.5 \pm 0.2$ & $18.4 \pm 3.2$ \\
\hline Chromium & & & & \\
\hline Mugil cephalus & 46 & 1.9 & $0.3 \pm 0.1$ & $6.0 \pm 2.1$ \\
\hline Eleginops maclovinus & 46 & 1.4 & $0.2 \pm 0.1$ & $3.2 \pm 0.9$ \\
\hline & & & & \\
\hline Lead & & & & \\
\hline Mugil cephalus & 46 & 3.4 & $0.4 \pm 0.1$ & $11.1 \pm 2.6$ \\
\hline Eleginops maclovinus & 46 & 1.6 & $0.3 \pm 0.1$ & $4.0 \pm 1.1$ \\
\hline
\end{tabular}

${ }^{a}$ Each value is the average of three measurements. 
According to results, the copper content in the muscle of both species taken from the mouths of the Maule and Mataquito rivers varied between 0.5 and $36.2 \mathrm{mgkg}^{-1}$ (dry wt), higher values than those recorded in the bibliography (Table 4), where the values in muscle from three species of fish taken from the Mediterranean Sea (Turkey) fluctuated between 0.04 and $5.43 \mathrm{mg} \mathrm{kg}^{-1}$ (dry wt) ${ }^{27}$; between 0.9 and $6.9 \mathrm{mg} \mathrm{kg}^{-1}$ (dry wt) in muscle from the species $L$ ramada taken from the Tagu Estuary (Portugal) ${ }^{2}$; and between not detected and $1.68 \mathrm{mgkg}^{-1}$ (wet wt) in the species $L$ cephalus from south-western Turkey ${ }^{28}$ (Table 4 ).

The results for chromium in muscle of the two species taken from the river mouths fluctuated between 0.2 and $6.3 \mathrm{mg} \cdot \mathrm{kg}^{-1}$ (dry wt), values which are in the same range as those presented by other authors in muscle of different species of fish from various sites ${ }^{27-29}$ (Table 4). For lead, the levels of concentrations in the two species from the mouths of the Maule and Mataquito rivers varied between 0.2 and $11.2 \mathrm{mg} \mathrm{kg}^{-1}$ (dry wt), with the maximum concentrations being slightly higher than that recorded for the species P. minutus from the Tagu Estuary ${ }^{2}$ with $8.9 \mathrm{mg} \cdot \mathrm{kg}^{-1}$ (dry wt) (Table 4).

Table 4. Selected references of metal concentrations ( $\mathrm{mgkg}^{-1} \mathrm{dry} \mathrm{wt}$ ) in muscle of fish from different geographical areas (mean values and ranges).

\begin{tabular}{|c|c|c|c|c|c|}
\hline Sites & Species & $\mathrm{Cu}$ & $\mathrm{Cr}$ & $\mathrm{Pb}$ & References \\
\hline Mediterranean Sea & S. undosquamis & $0.04-3.56$ & $0.21-3.13$ & $1.12-6.95$ & [27] \\
\hline \multirow[t]{2}{*}{ Turkey } & M. barbatus & $0.24-5.43$ & $0.69-6.46$ & $0.32-4.83$ & \\
\hline & S. aurata & $0.08-3.46$ & $0.07-3.48$ & $0.19-6.23$ & \\
\hline Tagus Estuary & P. minutus & $3.4-4.4$ & - & $5.6-8.9$ & [2] \\
\hline \multirow[t]{2}{*}{ Portugal } & S. senegalensis & $1.0-1.4$ & - & $1.6-2.9$ & \\
\hline & L. ramada & $0.9-6.9$ & - & $1.1-3.7$ & \\
\hline Yatagan basin & L. cephalus & nd - 1.68 & nd -4.15 & nd -0.48 & {$[28]$} \\
\hline \multicolumn{6}{|l|}{ South-western Turkey ${ }^{\mathrm{a}}$} \\
\hline Lake Uluöz & L. cephalus & $1.6 \pm 0.12$ & $1.6 \pm 0.14$ & $1.7 \pm 0.14$ & [29] \\
\hline \multicolumn{6}{|l|}{ Turkey } \\
\hline Maule Estuary & M. cephalus & $0.5-36.2$ & $0.3-6.3$ & $0.4-11.2$ & Present study \\
\hline Chile & E. maclovinus & $0.8-13.2$ & $0.2-5.6$ & $0.2-9.6$ & \\
\hline Mataquito Estuary & M. cephalus & $0.6-23.2$ & $0.3-6.0$ & $0.4-11.1$ & Present study \\
\hline Chile & E. maclovinus & $0.5-18.4$ & $0.2-3.2$ & $0.3-4.0$ & \\
\hline Tolerance level in fish & & 30.0 & - & 2.0 & {$[30]$} \\
\hline \multicolumn{6}{|l|}{ (FAO/WHO, 1989) } \\
\hline Tolerance level in fish & & 120 & 8.0 & - & [31] \\
\hline EPA & & & & & \\
\hline
\end{tabular}

${ }^{a}$ Results expressed based on fresh weight.

According to the results obtained and the average values of the concentrations of each of the elements (Tables 2 and 3), it was shown that the levels of $\mathrm{Cu}$ in the two species of fish studied originating from the mouths of the Maule and Mataquito rivers do not exceed the limits established by $\mathrm{FAO}^{30}$, which indicates a maximum of $30 \mathrm{mgkg}^{-1}$, nor those permitted by EPA ${ }^{31}$ which accepts up to $120 \mathrm{mg} \mathrm{kg}^{-1}$. With respect to lead, the averages obtained for the species Mugil cephalus taken from the mouths of the two rivers exceed the limit established by FAO, which indicates a maximum of $2.0 \mathrm{mg} \cdot \mathrm{kg}^{-1}$, however the average concentrations of $\mathrm{Pb}$ in the species Eleginops maclovinus do not exceed the permitted concentration levels at the two monitoring points. For $\mathrm{Cr}$ no levels established by FAO are reported, however the concentrations recorded do not exceed those established by EPA, which indicates a maximum of $8.0 \mathrm{mg} \mathrm{kg}^{-1}$.

To establish a ratio between the different variables considered (species, metals and monitoring points), one and two way ANOVAS were done with $\mathrm{P}<0.05$. For the one way Anovas, each of the species (Mugil cephalus and Eleginops maclovinus) was considered, comparing the two monitoring sites and with each of the metals $(\mathrm{Cu}, \mathrm{Cr}$ and $\mathrm{Pb})$ as the dependent variable, with no significant differences being recorded for any of the cases considered.

For the two way analysis, the two species of fish were considered in relation to the two sampling points and the concentration of each metal. The results indicate that when $\mathrm{Cu}$ and $\mathrm{Cr}$ are considered, significant differences only occur at the level of the fish, i.e. between Mugil cephalus and Eleginops maclovinus, with no significant differences presented in the other variables. In the case of $\mathrm{Pb}$, there are no significant differences at the level of species, sampling points or the interaction between them.

\section{CONCLUSIONS}

The present study provides information on the concentration of copper, chromium and lead in two species of fish consumed in large quantities by the local population round the mouths of the Maule and Mataquito rivers, located in the central zone of Chile. Based on the samples analysed, the concentrations of copper and chromium in the edible parts of the fish are generally below the legal concentrations proposed by FAO and EPA, however the high concentration of lead in the species Mugil cephalus from both estuaries is a cause for concern, 
as it exceeds the permitted limits, and this element may be a potential indicator of the degree of contamination of the two river mouths as a result of domestic, industrial and agricultural discharges occurring in the Maule Region, (Chile).

\section{ACKNOWLEDGEMENTS}

The authors of the present work are grateful to the Report Financing Programme of the Maule Regional Government (Maule Region, Chile) and the Environmental Chemistry Laboratory of the Institute of Natural Resources Chemistry of the University of Talca, Chile.

\section{REFERENCES}

1. J. E. Marcovecchio, Sci of the Total Environ 323, 219, (2004).

2. S. Franca, C. Vinagre, I. Cacador and H. N. Cabral, Baseline / Marine Pollution 50, 993, (2005).

3. J. Chiang, Revista Ambiente y Desarrollo. IV (1-2), Chile, 1998; pp $67-$ 72.

4. D. Mendil, O. D. Uluözlü, E. Hasdemir, M. Tüzen, H. Sari and M. Suicmez, Food Chemistry, 90, 175, (2005).

5. S. P. Lall, In A. Ruiter (Ed.), Fish and fishery products. CAB International, 1995; pp. 187-213.

6. J. Tapia, E. Durán, F. Peña, E. Hauenstein, C. Bertrán, R Schlatter, L. Vargas and C. Jiménez, J. Chil. Chem. Soc., 51, 2, 901, (2006).

7. S. A. Mansour \& M. M. Sidky, Food Chemistry, 78, 15, (2002).

8. F. Yilmaz, N. Ozdemir, A. Demirak and L. Tuna. Food Chemistry, 100, 830, (2007).

9. F. M. El-demerdash \& E. I. Elegamy, International Journal of Environmental Health Research. 9, 173, (1999).

10. M. Dural, M. Z. L. Göksu and A. A. Özak, Food Chemistry, 102, 415, (2007).

11. P. V. Hadson, Aquatic Toxicology, 11, 3, (1988).

12. Harrison, G., Principios de Medicina Interna. Mc Graw - Hill. Tercera Edición. (1996).

13. J. Rebolledo, Revista Geográfica de Chile Terra. Australis, 30, 1987; pp. 95-125.
14. L. Chuecas, Programa Cuenca del Bío-Bío. Tomo I Ed. Universidad de Concepción, 1989; pp. 51-60.

15. J. Tapia, Evaluación de la contaminación por cromo en un sistema fluvial de Chile Central: Una propuesta para la disminución en su origen. Tesis Doctoral. Universidad de Concepción, Chile, (1997).

16. S. Basualto and J. Tapia, Bol. Soc. Chil. Quim. 42, 371, (1997).

17. C.Bruhn, L. Villablanca, V. Campos, S. Basualto and J. Tapia, Bol. Soc. Chil. Quim. 42, 83, (1997).

18. S. Basualto, J. Tapia, F. Cruces, C. Bertrán, R Schlatter, F. Peña and E. Hauenstein, J. Chil. Chem. Soc. 51, 993. (2006).

19. J. M. Hellawell, Mellamby, K. (Ed.) N.Y. Pollution Monitoring Series, Elsevier Applied Science, 546, (1989).

20. INE (2002), Dirección General del Maule, Región del Maule, Chile

21. Antecedentes Generales VII Región (1992), Proyecto Oficina Fomento de Inversión; Gobierno Regional, Universidad de Talca y Junta de adelanto del Maule, Región del Maule, Chile.

22. DJH. Phillips, Environment on Pollution, 13, 282, (1977).

23. W. Ashraf, Z. Seddigi, A. Abulkibash and M. Khalid, Environmental Monitoring and Assessment, 117, 271, (2006).

24. F. Henry, R. Amara, L. Courcot, D. Lacouture and M. L. Bertho, Environment International, 30, 675, (2004).

25. C. H. Gammons, D. G. Slotton, B. Gerbrandt, W. Weight, C. A. Young, R. L. McNearmy, E. Cámac, R. Calderón and H. Tapia, Sci Total Environ 368, 637, (2006).

26. M. Reddy, J.S. Reif, A. Bachand and S.H. Ridgway. Sci Total Environ 274, 171, (2001).

27. A. Türkmen, M. Türkmen, Y. Tepe and I. Akyurt, Food Chemistry, 91, $167,(2005)$

28. A. Demirak, F. Yilmas, A. L. Tuna and N. Ozdemir, Chemosphere, 63, 1451, (2006).

29. D. Mendil, O.D. Uluözlü, E. Hasdemir, M. Tüzen, H. Sari and M. Suicmez, Food Chemistry, 90, 175, (2005).

30. C.E. Nauen, Compilation of legal limits for hazardous substances in fish and fishery products. FAO Fish Circular 764 (1983), p102.

31. EPA. Risk Assessment: Technical Background Information. RBG Table. Available from http:/www.epa.gov/reg3hwmd/risk/rbc1003.pdf. 